\section{JURNAL EKONOMI EFEKTIF}

ISSN : $2622-8882$, E-ISSN : 2622-9935

Jurnal Ekonomi Efektif, Vol. 4, No. 1, Oktober 2021 @Prodi Manajemen Fakultas Ekonomi Universitas Pamulang

\title{
PENGARUH KUALITAS JASA DAN KEWAJARAN HARGA TERHADAP KEPUASAN PELANGGAN MENGGUNAKAN JASA GRAB (Studi Kasus Pada Pelanggan Grab Kota Sorong)
}

\author{
Rismawati $^{1 *}$, Ahmad Jamil'², Febry Jein Andjar ${ }^{3}$ \\ Universitas Muhammadiyah, Sorong, Papua Barat, Indonesia \\ $\underline{\text { rsmwtrauf5499@gmail.com }{ }^{1 *}}$, jamilscout@gmail.com ${ }^{2}, \underline{\text { febryojaneth@ gmail.com }}{ }^{3}$
}

Manuskrip: September -2021; Ditinjau: September: -2021; Diterima: September-2021; Online: Oktober-2021; Diterbitkan: Oktober-2021

\begin{abstract}
ABSTRAK
Penelitian ini bertujuan untuk menjelaskan Pengaruh Kualitas Jasa dan Kewajaran Harga terhadap Kepuasan Pelanggan menggunakan Jasa Grab. Populasi 97 pelanggan Grab Kota Sorong. Metode pengambilan sampel menggunakan purposive sampling. Metode pengolahan dan analisis data yaitu menggunakan analisis kuantitatif yang meliputi uji validitas dan reliabilitas, uji asumsi klasik, analisis regresi berganda, uji hipotesis melalui uji $\mathrm{F}$ dan uji t serta analisis koefisien regresi $\left(\mathrm{R}^{2}\right)$. Hasil analisis data menunjukkan bahwa kualitas jasa berpengaruh positif terhadap kepuasan pelanggan sebesar 4,361 dengan probabilitas sebesar 0,000. Kewajaran harga berpengaruh positif terhadap kepuasan pelanggan sebesar 4,061 dengan probabilitas 0,000 . Kualitas jasa dan kewajaran harga berpengaruh positif sebesar 77,912 dengan probabilitas sebesar 0,000. Hal ini menunjukkan bahwa semua variabel independen yaitu kualitas jasa dan kewajaran harga berpengaruh signifikan secara simultan.
\end{abstract}

Kata Kunci: Kualitas Jasa, Kewajaran Harga, Kepuasan Pelanggan

\section{ABSTRACT}

This study aims to explain the effect of service quality and fairness on price on customer satisfaction using Grab services. Population 92 Grab City Sorong customers. The sampling method used was purposive sampling. Data processing and analysis methods are using quantitative analysis which includes validity and reliability tests, classical assumption tests, multiple regression analysis, hypothesis testing through the $F$ test and $t$ test and regression coefficient analysis (R2). The results of data analysis show that service quality has a positive effect on customer satisfaction by 4.361 with a probability of 0.000. Price fairness has a positive effect on customer satisfaction by 4,061 with a probability of 0.000. amounting to 77.912 with a probability of 0.000. This shows that all independent variables, namely service quality and fairness of price, have a significant effect simultaneously

Keywords: Service Quality, Reasonable Price, Customer Satisfaction 


\section{PENDAHULUAN}

\section{A. Latar Belakang Masalah}

Perkembangan dunia dalam usaha seakan tak pernah pupus. Pesatnya persaingan jasa transportasi di Indonesia disebabkan karena pelanggan yang semakin cerdas, sadar harga dan banyak menuntut. Kemajuan teknologi komunikasi seperti internet juga ikut berperan meningkatkan persaingan, karena memberi pelanggan akses informasi yang lebih banyak tentang berbagai macam produk yang ditawarkan. Kondisi tersebut menyebabkan pelanggan memiliki pilihan yang lebih banyak dalam menggunakan uangnya. Bagi konsumen, biaya yang dikeluarkan untuk memenuhi kebutuhan dan keinginan harus sesuai dengan yang diharapkan sehingga menimbulkan kepuasan.

Kepuasan konsumen merupakan hal penting yang harus dicapai oleh perusahaan, (Keller, 2006) menyatakan bahwa kepuasan konsumen merupakan perasaan senang atau kecewa seseorang yang timbul karena membandingkan kinerja yang dipersepsikan produk (atau hasil) terhadap ekspetasi mereka. Konsumen akan merasa senang atau kecewa terbentuk di dalam diri konsumen melalui kualitas jasa yang telah diberikan Grab. Faktor kualitas jasa dan harga yang wajar menjadi salah satu faktor dalam meningkatkan kepuasan yang diperoleh oleh konsumen setelah melakukan pembelian.

Kualitas jasa yang baik merupakan hal yang sangat penting bagi konsumen, kualitas jasa yang diberikan Grab sangatlah penting untuk mendapatkan kepuasan pelanggannya. Namun untuk memahami bagaimana mengevaluasi kualitas yang diterima oleh konsumen tidaklah mudah. Kualitas jasa menurut (Tjiptono, 2015) pada dasarnya kualitas suatu jasa yang dipersepsikan pelanggan terdiri atas dua dimensi. Dimensi pertama technical Quality (outcome dimension) berkaitan dengan kualitas output jasa yang dipersepsikan pelanggan. Dimensi kedua, Functional Quality (process-related dimension) berkaitan dengan kualitas cara penyampaian jasa atau menyangkut proses transfer kualitas teknis, output atau hasil akhir jasa dari penyedia jasa kepada pelanggan.

Konsumen menggunakan kewajaran harga sebagai bahan pertimbangan dalam menentukan pilihan harga Grab yang masih wajar atau tidaknya wajar, kapan sebaiknya transaksi dilakukan serta berapa besar kebutuhan yang akan dipakai sesuai dengan kemampuan daya konsumen. Suatu produk harus tepat dalam penentuan dan penetapan harga jualnya sehingga dapat diterima oleh konsumen dengan tidak mengabaikan kualitas produk tersebut. (Kotler, 2005) dalam arti yang sempit mengartikan bahwa harga sebagai jumlah uang yang dibebankan atas suatu produk atau jasa. (Xia, 2004) mengungkapkan bahwa penilaian dari kewajaran harga atau price fairness kemungkinan besar didasarkan pada perbandingan transaksi yang melibatkan berbagai pihak. Ketika dirasakan terjadi perbedaan harga, maka tingkat kesamaan antara transaksi merupakan unsur penting dari penilaian kewajaran harga. Penilaian kewajaran tergantung pada beberapa besar komperatif pihak yang terlibat dalam transaksi.

Kota Sorong merupakan salah satu kota yang padat aktivitas, dalam kesehariannya masyarakat melakukan berbagai kegiatan dan berpergian dari satu tempat ke tempat lainnya. Hal ini tentu membuat kebutuhan akan transportasi semakin meningkat terlebih bagi mereka yang tidak memiliki kendaraan pribadi. Transportasi dapat dijumpai dengan pergi ke terminal, halte, pangkalan ataupun menunggu di jalur yang mereka bisa lalui. Namun hal ini sepertinya dianggap kurang inovatif mengingat saat ini perkembangan teknologi sudah semakin modern.

Melihat keadaan semakin modern sebuah perusahaan mendirikan jasa angkutan umum yang memanfaatkan teknologi dengan menggabungkan antar internet dan transportasi umum yaitu Grab. Grab merupakan layanan transportasi, perusahaan yang mempunyai layanan lain seperti pengantaran makanan dan pembayaran yang bisa diakses 
lewat aplikasi mobile. Grab merupakan pelayanan yang memuaskan konsumen dengan menjemput konsumen hingga depan rumah.

Grab merupakan salah satu platform layanan on demand (sesuai permintaan) yang bermarkas di singapura. Didirkan pada Juni 2012 (dikenal sebagai GrabTaxi hingga 2016) pendiri bernama Anthony Tan Tan Hooi Ling. Grab didirikan di Malaysia sebelum kemudian pusat mereka ke Singapura. Berawal dari layanan transportasi, perusahaan tersebut kini telah mempunyai layanan lain seperti pengantaran makanan dan pembayaran yang bisa diakses lewat aplikasi mobile. (Https://Www.Grab.Com)

Grab masuk pada kota Sorong didirikan pada bulan Desember 2019. Mitra Grab Motor berjumlah 237 dan Mitra Grab Mobil berjumlah 156. Grab mempunyai jenis pelayanan angkutan perjalanan seperti GrabCar (mobil) GrabBike (Motor), jika ingin melakukan pembelian makanan melalui GrabFood, dan jika ingin mengirim barang dapat menggunakan GrabExpress. (sumber Admin Grab Sorong dikutip pada tanggal 3 maret 2021)

Adapun Keputusan Menteri Perhubungan Republik Indonesia Nomor KP 348 Tahun 2019 tentang Pedoman Perhitungan Biaya Jasa Penggunaan Sepeda Motor yang Digunakan Untuk Kepentingan Masyarakat yang Dilakukan Dengan Aplikasi.bahwa sesuai ketentuan Pasal 11 ayat 5 Peraturan Menteri Perhubungan Nomor PM 12 Tahun 2019 tentang Perlindungan Keselamatan Pengguna Sepeda Motor yang digunakan untuk Kepentingan masyarakat, menteri perhubungan menetapkan pedoman perhitungan biaya jasa pengguna sepeda motor yang digunakan untuk kepentingan masyarakat yang dilakukan dengan aplikasi.

Biaya jasa sepeda motor yang digunakan untuk kepentingan masyarakat yang dilakukan dengan Aplikasi terdiri dari Biaya Jasa Batas Bawah, Biaya Jasa Batas Atas dan Biaya jasa Minimal. Biaya jasa minimal merupakan biaya jasa yang harus dibayarkan oleh penumpang untuk jarak tempuh paling jauh 4 kilometer.

Besaran biaya Jasa Untuk Wilayah Papua yaitu:

1) Biaya jasa batas bawah sebesar $\operatorname{Rp} 2.100 / \mathrm{km}$

2) Biaya Jasa Batas atas sebesar RP 2.600

3) Biaya Jasa Minimal dengan Rentang Biaya Jasa antara Rp 7.000 s.d Rp 10.000

Berdasarkan penjelasan diatas, mendorong peneliti untuk melakukan penelitian dengan judul "Pengaruh Kualitas Jasa dan Kewajaran Harga terhadap Kepuasan Pelanggan menggunakan Jasa Grab"

\section{B. Rumusan Masalah}

Berdasarkan uraian latar belakang yang telah ada, maka permasalahan yang dapat dikemukakan adalah sebagai berikut :

1. Apakah Kualitas Jasa berpengaruh terhadap Kepuasan Pengguna Jasa Grab ?

2. Apakah Kewajaran Harga berpengaruh terhadap Kepuasan Pengguna Jasa Grab ?

3. Apakah Kualitas Jasa dan Kewajaran Harga berpengaruh terhadap Kepuasan Pengguna Jasa Grab?

\section{Tujuan Penelitian}

1. Untuk mengetahui apakah ada pengaruh kualitas jasa terhadap kepuasan pengguna jasa Grab.

2. Untuk mengetahui apakah ada pengaruh kewajaran harga terhadap kepuasan pengguna jasa Grab.

3. Untuk mengetahui apakah ada pengaruh kualitas jasa dan kewajaran harga terhadap kepuasan pengguna jasa Grab. 


\section{METODE PENELITIAN}

\section{Populasi}

Populasi dalam penelitian ini berjumlah 3000 responden Pelanggan Grab yang berdomisili di Kota Sorong Papua Barat.

2. Sampel

Sampel dalam penelitian ini berjumlah 97 responden.

\section{Jenis Penelitian}

Jenis penelitian yang dipakai adalah korelasi, dimana suatu penelitian yang melibatkan tindakan pengumpulan data guna menentukan, apakah hubungan dan tingkat hubungan antara dua variabel atau lebih.

\section{Metode Analisis Data}

Dalam menganalisis data digunakan uji instrumen, uji asumsi klasik, regresi, koefisien determinasi dan uji hipotesis.

\section{HASIL PENELITIAN}

\section{A. Analisis Deskriptif}

Pada pengujian ini digunakan untuk mengetahui skor minimum dan maksimum, mean score dan standar deviasi dari masing-masing variabel. Adapun hasilnya sebagai berikut:

Tabel 1. Hasil Analisis Descriptive Statistics

\section{Descriptive Statistics}

\begin{tabular}{lr|r|r|r|r} 
& N & Minimum & Maximum & Mean & Std. Deviation \\
\hline Kualitas Jasa (X1) & 97 & 41 & 75 & 58.68 & 7.112 \\
\hline Kewajaran Harga (X2) & 97 & 19 & 45 & 34.60 & 5.261 \\
\hline Kepuasa Pelanggan (Y) & 97 & 21 & 45 & 33.93 & 5.017 \\
\hline Valid N (listwise) & 97 & & & & \\
\hline
\end{tabular}

Kualitas Jasa diperoleh varians minimum sebesar 41 dan varians maximum 75 dengan mean score sebesar 58,68 dengan standar deviasi 7,112.

Kewajaran Harga diperoleh varians minimum sebesar 19 dan varians maximum 45 dengan mean score sebesar 34,60 dengan standar deviasi 5,261.

Kepuasan Pelanggan diperoleh varians minimum sebesar 21 dan varians maximum 45 dengan mean score sebesar 33,93 dengan standar deviasi 5,017.

\section{B. Analisis Verifikatif}

Pada analisis ini dimaksudkan untuk mengetahui pengaruh variabel independen terhadap variabel dependen. Adapun hasil pengujian sebagai berikut:

\section{1) Analisis Regresi Linier Berganda}

Uji regresi ini dimaksudkan untuk mengetahui perubahan variabel dependen jika variabel independen mengalami perubahan. Adapun hasil pengujiannya sebagai berikut:

\begin{tabular}{|c|c|c|c|c|c|}
\hline \multirow[b]{3}{*}{ Model } & \multicolumn{3}{|c|}{ Coefficients $^{a}$} & \multirow[b]{3}{*}{$\mathrm{t}$} & \multirow[b]{3}{*}{ Sig. } \\
\hline & \multicolumn{2}{|c|}{$\begin{array}{l}\text { Unstandardized } \\
\text { Coefficients }\end{array}$} & \multirow{2}{*}{$\begin{array}{c}\text { Standardized } \\
\text { Coefficients } \\
\text { Beta } \\
\end{array}$} & & \\
\hline & $\mathrm{B}$ & Std. Error & & & \\
\hline $\begin{array}{ll} & \text { (Constant) }\end{array}$ & 2.599 & 2.640 & & .984 & .328 \\
\hline Kualitas Jasa (X1) & .306 & .070 & .434 & 4.361 & .000 \\
\hline Kewajaran Harga (X2) & .386 & .095 & .405 & 4.064 & .000 \\
\hline
\end{tabular}

a. Dependent Variable: Kepuasan Pelanggan (Y)

Berdasarkan hasil pengujian pada tabel di atas, diperoleh persamaan regresi $Y$ $=2,599+0,306 \mathrm{X}_{1}+0,386 \mathrm{X}_{2}$. Dari persamaan tersebut dijelaskan sebagai berikut: 
a) Konstanta sebesar 2,599 diartikan jika kualitas jasa dan kewajaran harga tidak ada, maka telah terdapat nilai kepuasan pelaanggan sebesar 2,599 point.

b) Koefisien regresi kualitas jasa sebesar 0,306, angka ini positif artinya setiap ada peningkatan kualitas jasa sebesar 0,306 maka kualitas jasa juga akan mengalami peningkatan sebesar 0,306 point.

c) Koefisien regresi kewajaran harga sebesar 0,386, angka ini positif artinya setiap ada peningkatan kewajaran harga sebesar 0,386 maka kewajaran harga juga akan mengalami peningkatan sebesar 0,386 point.

\section{2) Analisis Koefisien Determinasi}

Analisis koefisien determinasi dimaksudkan untuk mengetahui besarnya persentase pengaruh dari variabel independen terhadap variabel dependen baik secara parsial maupun simultan. Adapun hasil pengujian sebagai berikut:

Tabel 3. Hasil Pengujian Koefisien Determinasi kualitas jasa dan kewajaran harga Terhadap Kepuasan pelanggan.

\begin{tabular}{|c|c|c|c|c|}
\hline \multicolumn{5}{|c|}{ Model Summary } \\
\hline Model & $\mathrm{R}$ & R Square & $\begin{array}{l}\text { Adjusted R } \\
\text { Square }\end{array}$ & $\begin{array}{l}\text { Std. Error of the } \\
\text { Estimate }\end{array}$ \\
\hline 1 & $.790^{\mathrm{a}}$ & .624 & .616 & 3.110 \\
\hline
\end{tabular}

Angka koefisien korelasi (R) sebesar 0,624. Hal ini berarti hubungan antar variabel independen dengan variabel dependen sebesar 62,4\%. Dari angka tersebut dapat diambil kesimpulan bahwa hubungan antara variabel independen dengan variabel dependen sangat kuat.

Besarnya Adjust R Square $\left(\mathrm{R}^{2}\right)$ adalah 0,616 . Hasil perhitungan statistik ini berarti bahwa kemampuan variabel independen dalam menerangkan variasinya perubahan variabel dependen sebesar $61,6 \%$, sedangkan sisanya sebesar $38,4 \%$ $(100 \%-61,6 \%)$ diterangkan oleh faktor-faktor lain di luar model regresi yang dianalisis.

\section{3) Uji Hipotesis}

\section{Uji hipotesis Parsial (Uji t)}

Pengujian hipotesis dengan uji t digunakan untuk mengetahui hipotesis parsial mana yang diterima.

Hipotesis pertama: Terdapat pengaruh yang signifikan antara kualitas jasa terhadap kepuasan pelanggan

Tabel 4. Hasil Uji Hipotesis Kualitas Jasa Terhadap Kepuasan Pelanggan. Coefficients $^{\text {a }}$

\begin{tabular}{|c|c|c|c|c|c|c|}
\hline \multirow{3}{*}{\multicolumn{2}{|c|}{ Model }} & \multirow{2}{*}{\multicolumn{2}{|c|}{$\begin{array}{l}\text { Unstandardized } \\
\text { Coefficients }\end{array}$}} & \multirow{3}{*}{$\begin{array}{c}\text { Standardized } \\
\text { Coefficients } \\
\text { Beta }\end{array}$} & \multirow[b]{3}{*}{$\mathrm{t}$} & \multirow[b]{3}{*}{ Sig. } \\
\hline & & & & & & \\
\hline & & $\mathrm{B}$ & Std. Error & & & \\
\hline & (Constant) & 2.599 & 2.640 & & .984 & .328 \\
\hline & Kualitas Jasa (X1) & .306 & 0.70 & .434 & 4.361 & .000 \\
\hline
\end{tabular}

a. Dependent Variable: Kepuasan Pelanggan (Y)

Berdasarkan hasil pengujian pada tabel di atas, diperoleh nilai t hitung $>\mathrm{t}$ tabel atau $(4,361>1,290)$, dengan demikian hipotesis pertama yang diajukan bahwa terdapat pengaruh yang signifikan atara kualitas jasa terhadap kepuasan pelanggan diterima. 
Tabel 5. Hasil Uji Hipotesis Kewajaran harga Terhadap Kepuasan pelanggan. Coefficients $^{\mathrm{a}}$

\begin{tabular}{|c|c|c|c|c|c|c|}
\hline \multirow{2}{*}{\multicolumn{2}{|c|}{ Model }} & \multicolumn{2}{|c|}{$\begin{array}{l}\text { Unstandardized } \\
\text { Coefficients }\end{array}$} & \multirow{2}{*}{$\begin{array}{l}\text { Standardized } \\
\text { Coefficients } \\
\text { Beta }\end{array}$} & \multirow[b]{2}{*}{$\mathrm{t}$} & \multirow[b]{2}{*}{ Sig. } \\
\hline & & B & Std. Error & & & \\
\hline 1 & (Constant) & 2.599 & 2.640 & & .984 & .328 \\
\hline & $\begin{array}{l}\text { Kewaajaran Harga } \\
\text { (X2) }\end{array}$ & .386 & .095 & .405 & 4.064 & .000 \\
\hline
\end{tabular}

a. Dependent Variable: Kepuasan Pelanggan (Y)

Berdasarkan hasil pengujian pada tabel di atas, diperoleh nilai t hitung $>\mathrm{t}$ tabel atau $(4,064>1,290)$, dengan demikian hipotesis kedua yang diajukan bahwa terdapat pengaruh yang signifikan antara kewajaran harga terhadap kepuasan pelanggan diterima.

\section{Uji Hipotesis Simultan (Uji F)}

Pengujian hipotesis dengan uji $\mathrm{F}$ digunakan untuk mengetahui hipotesis simultan yang mana yang diterima.

Hipotesis ketiga Terdapat pengaruh yang signifikan antara lingkungan kerja dan kepemimpinan terhadap kinerja karyawan.

Tabel 6. Hasil Uji Hipotesis Kualitas Jasa dan Kewajaran Harga Terhadap

Kepuasan Pelanggan.

\begin{tabular}{|c|c|c|c|c|c|c|}
\hline \multirow[b]{2}{*}{ Mode } & \multicolumn{6}{|c|}{$\begin{array}{c}\text { Kepuasan Pelanggan. } \\
\text { ANOVA }^{\mathbf{a}}\end{array}$} \\
\hline & & Sum of Squares & df & Mean Square & $\mathrm{F}$ & Sig. \\
\hline \multirow[t]{3}{*}{$\overline{1}$} & Regression & 1507.255 & 2 & 753.628 & 77.912 & $.000^{\mathrm{b}}$ \\
\hline & Residual & 909.240 & 94 & 9.673 & & \\
\hline & Total & 2416.495 & 96 & & & \\
\hline
\end{tabular}

Berdasarkan hasil pengujian pada tabel di atas, diperoleh nilai $\mathrm{F}$ hitung $>\mathrm{F}$ tabel atau $(77,912>2,359)$, dengan demikian hipotesis ketiga yang diajukan bahwa terdapat pengaruh yang signifikan atara kualitas jasa dan kewajaran harga terhadap kepuasan pelanggan diterima.

\section{Pembahasan Hasil Penelitian}

\section{Pengaruh Kualitas Jasa Terhadap Kepuasan Pelanggan}

Kepuasan Pelanggan, pada taraf signifikansi $10 \%$ dapat diketahui Hasil uji t dapat disimpulkan bahwa pada variabel kualitas jasa $\left(\mathrm{X}_{1}\right)$ seperti pada tabel 4.21 diatas diperoleh $\mathrm{t}$ hitung sebesar 4,361 dengan probabilitas sebesar 0,000 yang nilainya dibawah 0,1 . Dengan demikian mempunyai nilai positif dan nilai signifikansi kurang dari 0,1 maka Kualitas Jasa berpengaruh positif dan signifikan terhadap Kepuasan Pelanggan yang pernah menggunakan Jasa Grab Kota Sorong. Semakin tinggi Kualitas Jasa maka Kepuasan Pelanggan Grab Sorong akan meningkat.

\section{Pengaruh Kewajaran Harga terhadap Kepuasan Pelanggan}

kepuasan pelanggan, pada taraf signifikansi 10\% dapat diketahui Hasil uji t pada variabel kewajaram harga $\left(\mathrm{X}_{2}\right)$ seperti pada tabel 4.21 diatas diperoleh t hitung sebesar 4,064 dengan probabilitas 0,000 yang nilainya dibawah 0,1 . maka harga berpengaruh positif dan signifikan terhadap kepuasan pelanggan yang menggunakan jasa Grab. Pada tingkat kewajaran harga tertentu, apabila manfaat yang dirasakan pelanggan Grab meningkat, maka nilainya akan meningkat. Dengan demikian, apabila nilai yang dirasakan pelanggan Grab semakin tinggi, maka akan menciptakan kepuasan pelanggan. 


\section{Pengaruh Kualitas Jasa dan Kewajaran Harga terhadap Kepuasan Pelanggan}

Berdasarkan hasil perhitungan simultan kualitas jasa dan kewajaran harga terhadap kepuasan pelanggan. Diketahui hasil $\mathrm{F}$ hitung sebesar 77,912 dengan probabilitas sebesar 0,000 yang nilainya dibawah 0,1 . Hal ini menunjukkan bahwa semua variabel independen yaitu kualitas jasa dan kewajaran harga berpengaruh signifikan secara simultan (bersama-sama) terhadap kepuasan pelanggan menggunakan jasa Grab Sorong.

\section{KESIMPULAN DAN SARAN}

\section{Kesimpulan}

a. Kualitas Jasa berpengaruh signifikan terhadap Kepuasan Pelanggan. Uji hipotesis diperoleh nilai $t$ hitung $>\mathrm{t}$ tabel atau $(4,361>1,290)$.

b. Kewajaran Harga berpengaruh signifikan terhadap Kepuasan Pelanggan. Uji hipotesis diperoleh nilai t hitung $>\mathrm{t}$ tabel atau $(4,064>1,290)$.

c. Kualitas Jasa dan Kewajaran Harga berpengaruh signifikan terhadap Kepuasan Pelanggan. Uji hipotesis diperoleh nilai $\mathrm{F}$ hitung $>\mathrm{F}$ tabel atau $(77,912>2,359)$.

\section{Saran}

a. Harga terjangkau yang ditetapkan Grab menjadi salah satu hal yang dapat menarik perhatian pelanggan. Oleh karena itu keunggulan Grab dari segi Harga terjangkau ini dapat terus dijaga dan dipertahankan, agar dapat bersaing dengan Perusahaan lain.

b. Banyaknya pesaing di pasaran yang di hadapi oleh Perusahaan Grab, maka Perusahaan Grab harus mempertahankan dan meningkatkan kualitas jasa yang ada agar sesuai dengan harga yang ditawarkan ke konsumen.

c. Untuk mempertahankan pelanggan, perusahaan Grab harus mempertahankan harga yang terjangkau dan pelayanan jasa yang ditetapkan.

\section{DAFTAR PUSTAKA}

Ardani, W. (2019). Effect Of Product Innovation And Brand Awareness On Product Purchase Decisions Of PT. Unilever Indonesia. International Journal of Education, Information Technology, and Others, 2(1), 151-165.

Asih, P. S., et al. 2021). Analisis Faktor-Faktor Yang Mempengaruhi Keputusan Pembelian Produk Fastfood KFC Di Kota Sorong (Studi Kasus Mega Mall Kota Sorong). Jurnal Ilmiah PERKUSI, 1(3), 352-356.

Basu Swata, D. dan I. (2008). Manajemen Pemasaran Modern. Liberty.

Bitner, V. A. Z. M. J. (2008). Service Marketing. The McGraw-Hill Companies, Inc.

Buchari Alma. (2004). Manajemen Pemasaran dan Pemasaran Jasa (Edisi Revi). CV. Alfabeta.

Farida Jasfar. (2005). Manajemen Jasa Pendekatan Terpadu. Galia Indonesia.

Handoko, T. H. (2000). Manajemen Personalia dan Sumber Daya Manusia (Edisi ke 2). BPFE.

Husein Umar. (2005). Metode Penelitian Untuk Tesis dan Bisnis (Grafindo P).

J. Paul Peter, J. C. O. (2013). Perilaku Konsumen dan Strategi Pemasaran (Edisi 9). Salemba Empat.

Kanuk, S. dan. (2008). Perilaku Konsumen (Edisi 7). Indeks.

Keller, K. \&. (2006). Manajemen Pemasaran. PT. INDEKS.

Kotler, P, Astrong, G. (2012). Prinsip-prinsip Pemasaran (Edisi 12). Erlangga.

Kotler, P. (1980). Manajemen Pemasaran. Erlangga. 
Kotler, P. (2005). Manajemen Pemasaran. PT Macanan Jaya.

Kotler, Philip, dan K. L. K. (2009). Manajemen Pemasaran (Edisi ke 1). Erlangga.

Lovelock, C, dan J. W. (2011). Pemasaran Jasa Perspektif (Edisi 7). Erlangga.

Lupiyoadi dan Hamdani. (2006). Manajemen Pemasaran Jasa (Edisi kedu). Salemba Empat. Maddinsyah, A., et al. (2020). Desain Formulasi Dan Implementasi Bisnis Strategik Dengan Pendekatan Business Model Canvas (BMC) Terintegrasi Kerangka Integrated Performance Management System (IPMS) Pada Koperasi Asperindo. Inovasi, 7(2), 67-76.

Malhotra. (2007). Marketing Research An Applied Orientation (Internasio). Pearson.

Mangkunegara, A. A. A. P. (2009). Manajemen Sumber Daya Manusia. Remaja Rosdakarya.

Molina, C. . (2007). An Integrated Model of Price Satisfaction and Loyality. Journal of Product \& Brand Management.

Nazir, M. (2005). Metode Penelitian. Galia Indonesia.

Nursalam. (2008). Konsep dan Penerapan Metodologi Penelitian Ilmu Keperawatan. Salemba Medika.

Rasyid, N., et al. (2018). Pengaruh Bauran Pemasaran Terhadap Penjualan Pada PT. Nestle Indofood Citarasa Indonesia Di Makassar. SENTRALISASI, 7(2), 11-27.

Rosad, S. \&. (2015). Manajemen Pemasaran. IN MEDIA.

Sugiyono. (2011). Metode Penelitian Kuantitatif, Kualitatif dan R\&D. Alfabeta.

Sugiyono. (n.d.). Metode Penelitian Pendidikan Pendekatan Kuantitatif, Kualitatif dan R\&D. Alfabeta.

Tjiptono, F. (2008). Strategi Pemasaran (Edisi 3). ANDI.

Tjiptono, F. (2012). Strategi Pemasaran (Edisi 3). ANDI.

Tjiptono, F. (2014). Pemasaran Jasa-Prinsip Penerapan, dan Penelitian. ANDI.

Tjiptono, F. (2015). Strategi Pemasaran. ANDI.

Wangsi, M. M., et al. (2018). Perlindungan Konsumen Dalam Pelabelan Produk Menurut Ekonomi Islam. Sentralisasi, 7(1), 1-9. 